\title{
An Analysis of XBRL
} Adoption Towards Systemic Risk of
Financial Institutions Listed in NYSE

\author{
Andreas Suwardi ${ }^{1}$ and Valentina Tohang ${ }^{2}$,
}

\begin{abstract}
This research aims to test the impact of the mandatory adoption of XBRL towards the systemic risk of American financial institutions listed in New York Stock Exchange (NYSE) by utilizing 45 NYSE listed financial institutions for the time period of 2007-2012. The measure of systemic risk is based on SRisk by Acharya et al. (2012) which is available in the NYU Stern V-Lab. XBRL is a dummy variable, in which 0 represents a pre XBRL adoption period (2007-2008) while 1 represents an XBRL reporting environment (2011-2012). It is further interacted with Corporate Governance, which is measured using an index developed by Brown \& Caylor (2006). The result proves that XBRL do not significantly impact systemic risk of financial institutions listed in NYSE. The findings have been determined after having controlled firm size, capital ratio, leverage ratio and performance. ${ }^{3}$

\footnotetext{
${ }^{1}$ Bina Nusantara University, Indonesia

${ }^{2}$ Bina Nusantara University, Indonesia.

${ }^{3}$ This research focuses on the impact of XBRL towards systemic risk of financial institutions listed in NYSE. Apart from this, it will also test the impact of the adoption towards size, capital ratio, leverage and performance of the financial institutions. The sample includes all financial institutions listed in NYSE between the years of 2007-2012. The impact is determined by comparing the systemic risk of individual financial institutions pre and post the mandate of XBRL adoption in U.S. in 2009, in which the year 2009 and 2010 will be considered as transition periods due to the fact that XBRL is implemented through phased-in approach. Based on the data of 45 financial institutions, the findings will provide meaningful analysis and worthy discussions over the subject of XBRL. This research is expected to contribute to 1 . Companies (Financial Institutions) Financial institutions that are committed towards improving their corporate governance, can utilize this research to have an idea regarding how XBRL can serve as the tool to improve their corporate governance while also mitigating risky behaviors (which in turn reduces systemic risk) in order to further maximize their shareholder values. 2. Investors This research has the potential to provide investors with new insights which can assist in their decision making particularly regarding financial institutions. They will be acquired with the knowledge that financial firms with XBRL in place will provide them with timely and accurate information, improving their decision making. XBRL enhances transparency of financial firms which means that investors will face less difficulty in analyzing the financial information and will be able to properly asses the risk associated in their investments. 3. Government (Regulatory Agencies) In understanding the impact of XBRL towards systemic risk in U.S. financial institutions, regulatory agencies all around the world that
} 
JEL Classification: M48, M15.

Keywords: Systemic Risk, XBRL, Corporate Governance, Market Discipline, Financial Institution, Disclosure, NYSE, Risk Taking.

\section{INTRODUCTION}

In this globalized economy, the role of financial institutions has become increasingly critical. Its role as the intermediary to channel the capital across the economy has shown how essential this industry is for the economic development of a country as a whole. Schnyder (2012) stated that as long as the financial institutions are tightly regulated and their resources are distributed effectively, they can act as the catalyst for rapid economic development.

Unfortunately, in 2008, the collapse of some U.S. financial institutions has resulted in a global financial catastrophe which affected the economies of countries all over the world (Erkens et al. 2012). The causes of the crisis have been mainly linked to their excessive risk taking activities. Iqbal et al. (2015) and Mehran et al. (2011) noted that prior to the crisis, financial institutions have been engaging in high risk high return practices in order to maximize their shareholder value, which in turn increased their vulnerability towards systemic risk. In general, systemic risk is defined as the degree to which the activities or actions of an individual institution can affect the financial system as a whole. The higher the systemic risk, the greater the likelihood of the whole financial system to cripple; when a single institution diverges from the collective interest of the system. (Jickling \& Murphy, 2010).

Therefore, it amplifies the interest as to how the corporate governance of such highly regulated industry managed to fail to limit the apparent risky behaviors of financial institutions. The flaws in corporate governance originated from the fact that their business activities are much more complex and opaque than non-financial firms (Erkens et al. 2012). Levine (2011) stated that much financial related information is kept secret from the public. Hence, the role of equity holders as external governance is highly questionable. Iqbal et al. (2015) further stated that investors may have neglected or became less sensitive towards banking activities due to its growing complexity and opaqueness. Thus, this leads to the significance in the role of information and disclosures within the proper functioning of financial system. A study conducted by Mehran \& Mollineaux (2012) outlines the role of information and disclosures in mitigating both fundamental market failures and their proximate manifestations as governance failures. The study also shows a wide literature regarding the positive relationship between increased disclosures and the proper functioning of the market system as a whole.

are facing similar problems can utilize the same tool in order to limit the risk taking behavior of financial institutions and thereby reducing the systemic risk of the whole financial industry. Countries such as Indonesia (currently still in the process of developing XBRL Taxonomies since 2002), that has not mandated XBRL, can take into account the findings of this research to further evaluate the benefits or weaknesses in the XBRL implementation specifically towards financial institutions. 4. Academicians and Students This research provides students and academicians better understanding about the relationship of XBRL with systemic risk. Due to the fact that there have been limited studies connecting the two variables, this study serves as a starting point for researchers to further analyze how XBRL can potentially act as an appropriate tool to safeguard the well-being of the economy. Furthermore, as this research also assesses its impact on specifically the financial industry, researchers can further evaluate its impact on other industries. 
One of the ways to improve the current reporting procedure is through the implementation of eXtensible Business Reporting Language (XBRL). XBRL serves as the potential common delivery system to achieve the objective stated above. In today's dynamic, technology-driven environment, the use of XBRL will allow the utilization of standardized tagging system for both quantitative and qualitative information (Arnold et al. 2012). It can improve the reliability and efficiency of both financial and non-financial reporting, while making it easier for the shareholders to extract all information that they need (Blankerspoor et al., 2012). Yoon et al. (2011) also argued that the use of XBRL can reduce the cost of capital and information asymmetry in the capital market. However, Liu et al. (2014) pointed out that the application of XBRL can be hindered due to the nature of IT productivity, in which any new technology will require considerable amount of time to be implemented effectively in the capital market.

Despite the advancement of the use of XBRL and the importance of financial institutions, there has been a lack of detailed studies as to the impact of XBRL implementation to the industry. Furthermore, there have been limited studies as well as to how the XBRL can affect the systemic risk of the financial institutions. Based on those facts, this study aims to test the impact of the mandatory adoption of XBRL in American financial institutions listed in New York Stock Exchange (NYSE) towards systemic risk. NYSE is chosen as it has mandated the financial statement filings through XBRL since 2009, after the fall of its financial markets which initiated the global financial catastrophe. This study investigates whether the mandatory XBRL filings in the NYSE could reduce the systemic risk of American financial institutions by improving their corporate governance practices, considering how XBRL can enhance the information transparency in the market. It will also examine the change in impact of size, capital ratio, leverage and financial performance of firms on systemic risk pre and post XBRL adoption.

\section{Literature Review}

\subsection{Financial Institutions and Systemic Risk}

The main role of financial institutions is to act as intermediaries to allocate capital across the economy. They receive capitals in the form of deposits (or funds) from individuals or businesses with excess of resources and channel them into those with insufficient resources in the form of loans (Acharya \& Richardson, 2009). Financial institutions, especially LCFIs (Large Complex Financial Institutions) play a critical function in the development of the economy as a whole. Without them, the flow of capital will be stagnant as capital possessed by those in excess will not be properly channeled to those in need. Moreover, financial institutions are interconnected with one another. Generally, the owners of financial institutions are mostly institutional shareholders. These shareholders are also financial institutions that bought majority of the firm's shares. For example, $87.7 \%$ of the shares of an American insurance company, AIG (American International Group, Inc.), are owned by institutional or mutual funds holder (Yahoo Finance, 2016). Capital Group, another American financial services company, owns majority of these shares. Such interconnectedness and significance in their role in the economy render them to high systemic risk. Systemic risk is defined as the risk of a severe financial instability or collapse of the entire economy, which has been caused by a triggering event made at a company level (Jickling \& Murphy, 2010). This means that the failure of a LCFI will likely create a 'domino effect' for the rest of the firms operating in the same system. The 2008 financial crisis serves as an evidence of the systemic vulnerability of financial institutions. Such event had generated severe financial catastrophe in which financial institutions around the world were suffering losses worth billions 
of dollars and stock markets plunged to the very bottom. The global financial meltdown has been caused by the burst in the financial 'bubble' created by some financial institutions in U.S, most prominently being Bear Sterns, Lehman Brothers and AIG (American International Group, Inc). These firms have been involved in excessive risk taking activities in the form of subprime mortgages and credit default swaps which have resulted in credit boom and the creation of a housing bubble (Bullard et al., 2009). Mortgages are granted to individuals with little ability to fulfill their payment and on top of that, these mortgages received approval and guaranteed by credit rating companies. As a result, these firms filed bankruptcy during the crisis. As recently noted by Iqbal et al. (2015), there is a high correlation between the stand alone risk of individual financial institutions and the overall level of systemic risk. It is caused by the fact that financial institutions which practice excessively risky behaviors are likely to generate negative externalities towards the whole financial system by increasing systemic risk. The causes of the financial crisis and how it is linked to corporate governance mechanism of financial institutions will be further elaborated in the next section.

\subsection{Why Systemic Risk of Financial Institutions is triggered by Good Corporate Governance}

Corporate governance refers to a set of mechanism which controls and directs how the companies are being managed both internally and externally (Iqbal et al., 2015; Arnold et al., 2012). The proper use of corporate governance can bring numerous benefits for firms, in particular to mitigate the agency problem. Based on the value maximization principle, firms must operate in accordance to the interests of their owners instead of the management. Sound corporate governance will act as the control for firms to maximize the shareholders' value with fair and just decision making (Mehran \& Mollineaux, 2012). Schnyder (2012) also reaffirmed this statement, stating that sound corporate governance practices will indeed prevent shareholders from being exploited by internal management through an effective control mechanism. Thus, the interests of shareholders and management will be aligned, resolving agency problem.

Nonetheless, studies have shown that over the years, financial institutions have been increasingly exposed towards excessively risky behaviors. It is believed that it is actually caused by good corporate governance of financial institutions, in which based on the value maximization principle, firms must operate in the interests of their shareholders. They tend to maximize shareholders' value without considering the riskiness of their investment decisions (Arnold et al., 2012). Before the crisis, corporate governance mechanisms are designed in such a way that they encourage risk taking activities. Such mechanisms are mainly associated with the structure of boards in a firm. Boards can be considered as the most essential mechanism of corporate governance (Mehran \& Mollineaux, 2011). The risky behaviors of financial institutions are based on their decisions. Prior crisis, Belttrati \& Stulz (2012) documented that banks with more shareholder-friendly boards are associated with riskier investments (as cited in Iqbal et al. 2015). DeYoung et al. (2010) also found that banks have been altering CEO compensation to encourage risky behaviors in order to generate higher profit. DeYoung et al. (2010) found that CEOs' wealth has increased significantly before crisis. Moreover, as a sign of 'good corporate governance', board of directors must contain a strong independent representative who can act as an additional monitor over the activities of other directors and also the management. However, according to Mehran et al. (2011), there is a 'dark side to expertise' in boards of directors, in which these independent directors are only hired to further justify their 
risk taking activities. Shareholders will be misdirected into thinking that their boards are well monitored by the independent directors.

Therefore, based on the above examples, it raises questions as to what has caused the inability of the corporate governance mechanisms of financial institutions to detect and limit such risky behaviors. Many studies have connected such flaws with the opacity, complexity and obscurity in the activities of financial institutions (Claessens, 2006). According to Morgan (2002), the opacity of financial information originated from their nature of business activities. Their portfolio of loans is often unavailable to external stakeholders and derivative instruments are complex with risks that are too difficult to measure. Prior the crisis, financial institutions tend to be engaged in activities involving SPVs (Special Purpose Vehicles) and complex securitizations. Levine (2004) further states that "banks can alter the risk composition of their assets more quickly than most nonfinancial industries, and banks can readily hide problems by extending loans to clients that cannot service previous debt obligations." The opacity and complexity of financial institutions have clearly dismissed the ability of financial statement users to understand and assess risks over their activities.

\subsection{Role of Information and Disclosures in Mitigating Excessive Risk Taking Behaviors of Financial Institutions}

Many studies have suggested a correlation between the excessive risk taking behaviors of financial institutions with the opacity and complexity of their activities (Dhouibi et al. 2016; Bushman, 2016; Mehran \& Mollineaux, 2012; Nier \& Baumann, 2006). The studies listed have highlighted the importance in the role of transparency and understandability towards enhancing market discipline of financial institutions, which will in turn limit their risky behaviors. According to Nier \& Baumann (2006), market discipline can serve as a mechanism which will curb their intention to undergo excessively risky investment decisions, by making such activities more costly. This is based on the belief that market participants, which include but not limited to shareholders and investors, will likely react and exert pressure to financial institutions when they are undergoing extremely risky behaviors. Financial institutions, on the other hand, will have the incentive to act prudently and efficiently, having known that their activities are being observed by the market participants (Bushman, 2016). Hence, it is necessary for financial institutions to increase their quality of information available to their external stakeholders.

According to IASB (2013) this can be achieved by improving quality of common disclosures via a common delivery system. Disclosures made by firms are ways in which they communicate to their external stakeholders. Enhanced quality of disclosures will enable users of financial statements to acquire sufficient information which can assist them in their gathering, analysis and decision making process.

\subsection{XBRL as the Most Suitable Common Delivery System to Reduce Systemic Risk}

XBRL (eXtensible Business Reporting Language) refers to an international standard for digital business reporting, which utilizes XML (Extensible Markup Language) reporting language to enable automated communication of business and financial data (Kernan, 2008). It was first introduced by Charles Hoffman back in 1998 and since then, it has been experiencing rapid growth and is widely used in numerous capital markets, supporting both the financial and nonfinancial reporting by taking advantage of the advancement and immediacy of World Wide Web (Arnold et al. 2012). The significance in its growth can be seen from the fact that until today, 
there are about 50 countries that have adopted XBRL, some of which have even mandated its use.

Unlike the static data contained in PDF and HTML based reports, the data which uses XBRL format has its own meaning, descriptions and attributes. An XBRL instance document can be viewed as a system of barcodes in which each barcode contains its own information. Each 'code' or tagged data has its own element organized within the categorization scheme, known as taxonomy. The function of XBRL Taxonomy in literal terms is similar to a 'dictionary'. It contains diverse financial concepts, in which these concepts serve as descriptions or explanations of the tagged item from the XBRL Instance Document, depending on which element it is associated with.

XBRL has the potential to act as the most suitable delivery system which can mitigate the corporate governance problems associated with excessive risk taking behaviors of financial institutions. Blankerspoor et al. (2012) argued that the use of XBRL can enhance the transparency of the reporting firms, in which the reporting firms will be obliged to follow the pre-determined template and fill the required information. Such template will diminish the possibility of financial institutions failing to disclose relevant information to their external stakeholders. Furthermore, the XBRL tagging system extracts information directly from the company's database, ensuring that all relevant transactions are actually disclosed. Yoon et al. (2011) also pointed out that the use of XBRL will reduce the information asymmetry between the investors and the reporting firms through increased transparency. This helps reduce the investors' uncertainty and exposure to risk, as the use of XBRL will result in more reliable and easily accessible information which is imperative in the marketplace. Additionally, XBRL enhances understandability through the provision of a well-structured format and its tagging system. In particular, the tagging feature enables users to understand the relationship between each data and also the origin of its amount. As a result, the complex derivatives and SPVs employed by financial institutions will be made more understandable through the tagging system, giving investors the opportunity to properly asses their riskiness. Investors' decisions will be based on a more meaningful and richer data, which enables them to act as external monitors in measuring the risky behaviors of financial institutions and react when management is not operating based on their interests. Thus, they can exert pressure by forcing financial institutions to maintain high amount of capital and limit the amount of debt taken. When financial institutions are forced to maintain high amount of capital and low amount of liabilities, they have little ability to take on risky investments, which will in turn reduce the firms' exposures towards systemic risk. Moreover, based on the findings of Premuroso \& Bhattacharya (2008), there is a positive association between XBRL adoption and corporate governance, showing that XBRL serves as a tool which may help improve the corporate governance of financial institutions.

\section{Hypothesis Development}

The critical role of financial institutions in the economy and their high degree of interconnectedness, make them vulnerable towards systemic risk. According to Iqbal et al. (2015), financial institutions tend to engage in excessively risky behaviors in order to increase their profit. Such risky behaviors have increased their vulnerability towards systemic risk. As seen from the 2008 financial crisis, such behaviors were undetected and failed to be mitigated by the corporate governance mechanisms of financial institutions. Corporate governance is claimed 
to be the mechanism which should have detected such risky behaviors of financial institutions. According to Arnold et al. (2012) and Iqbal et al. (2015), the excessive risk taking activities of financial institutions are actually the result of good corporate governance practices. Based on the value maximization principle, financial institutions have the tendency to maximize the shareholders' value, without properly measuring their risky behaviors. Many studies have highlighted the lack of transparency and understandability in the activities of financial institutions as the primary cause for the failure to detect such behaviors (Dhouibi et al. 2016; Bushman, 2016; Mehran \& Mollineaux, 2012; Nier and Baumann, 2006). Such features diminished the function of market discipline in financial institutions. It is argued that market discipline is essential for the proper functioning of the market system as a whole, particularly among financial institutions, where it will enable external stakeholders to exert pressure when management of financial institutions is acting against their interests (Mehran \& Mollineaux, 2012). According to IASB (2013), this can be achieved through a common delivery system. Blankerspoor et al., 2012 and Yoon et al., 2012 claim that XBRL has the potential to act as the most suitable common delivery system. Many studies have found that XBRL adoption has resulted in increased transparency of firms and improved quality of financial information through increased flexibility and understandability. Hence, the tighter external control enabled by the mandatory adoption of XBRL in 2009 is expected to reduce the excessive risk-taking behaviors of the financial institutions, by acting as a complementary tool to resolve insufficiencies and flaws of current corporate governance mechanisms. This will in turn reduce the overall systemic risk of financial institutions listed in the New York Stock Exchange (NYSE). It is expected that the XBRL adoption will result in the reduction of systemic risk for the financial institutions listed in the NYSE.

H1: The mandatory adoption of XBRL will lower the systemic risk of financial institutions listed in the NYSE, through improved corporate governance.

\section{Data and Research Methodology}

The population for this research includes all financial institutions listed in NYSE, which totaled up to 361 firms. The reason for particularly choosing NYSE is due to the fact that NYSE is the largest stock exchange in the world in terms of its market capitalization. Many financial institutions listed in NYSE are claimed to be the source of financial crisis, given their systemic importance in the overall financial system. After having conducted the purposive sampling, the list is narrowed into 45 firms. The data of these 45 firms will be of 4 years, two years pre (20072008) and post (2011-2012) XBRL adoption, with a total of 180 observations. The reason for having chosen NYU Stern's V-Lab as the source of data for systemic risk is based on the support of wide literatures regarding the measure of systemic risk used. NYU Stern's V-Lab uses SRisk and MES which have been proposed by Acharya et al. (2012). Furthermore, NYU Stern's V-Lab specifically lists and ranks firms that contribute most towards the overall systemic risk. Thus, the financial institutions chosen are compiled of those that have considerable impact towards the systemic risk of the whole financial system. In regards to the research model, this study utilizes the following research variables listed in the table below. 
Table 1

Research Variables

\begin{tabular}{|c|c|c|}
\hline Classification & Variables & Formulas \\
\hline Dependent & SRisk & SRisk $_{i t}=k$ Debt $_{i t}-(1-k)\left(1-\right.$ LRMES $\left._{i t}\right) \times$ Equity $_{i t}$ \\
\hline \multirow{3}{*}{ Interaction } & XBRLenv & Dummy Variable $(0=$ pre adoption; $1=$ post adoption $)$ \\
\hline & $\begin{array}{l}\text { Corporate } \\
\text { Governance }\end{array}$ & $\begin{array}{l}\text { Points rewarded for every attribute achieved based on } \\
\text { Governance Index by Brown \& Caylor (2006) }\end{array}$ \\
\hline & $X B R L \times G o v$ & XBRLenv $\times$ Governance \\
\hline \multirow{4}{*}{ Control } & Size & $\log$ Total Assets (LOGTA) \\
\hline & Capital Ratio & $\frac{\text { Capital }}{\text { Total Assets }}$ \\
\hline & Leverage & $\frac{\text { Debt }}{\text { Capital }}$ \\
\hline & Return on Assets & $\frac{\text { Net Income }}{\text { Total Assets }}$ \\
\hline
\end{tabular}

Based on the above variables, the following model has been developed:

$$
\begin{aligned}
\text { SRisk }_{i t}= & \beta_{0}+\beta_{1} \text { XBRLenv } \\
& +\beta_{2} \text { Governance }_{i t}+\beta_{3} \text { XBRLenv } \times \text { Governance }_{i t} \\
& +\beta_{4} \text { Size }_{i t}+\beta_{5} \text { Capital ratio }_{i t}+\beta_{6} \text { Leverage }_{i t}+\beta_{7} \text { ROA A }_{i t}+\varepsilon_{i}
\end{aligned}
$$

Where SRisk is defined as the amount of capital financial institution i needs at time $\mathrm{t}$ amidst events of financial crisis and $X B R L \times G o v$ is an interaction variable of XBRLenv and Corporate Governance. The rest of the variables are defined in the above table.

\section{Findings and Discussions}

The research model is then run using the multiple linear regression analysis. The table below provides the summary of the results. As can be seen, the Adjusted $R^{2}$ is $68.4 \%$. Thus, this implies that the independent $(\mathrm{XBRL} \times \mathrm{GOV})$ and control (Size, Capital Ratio, Leverage Ratio and ROA) variables can explain the variances in SRisk by $68.4 \%$. The other $31.6 \%$ of the variances may be the result of other factors that are not included in the model such as regulations, deposit insurance, loan growth and non-interest income (Iqbal et al. 2015; Weiß et al. 2014). Moreover, the model has probability F-Statistics equal to 0.000 . Hence, the model can be deemed significant which implies that the model is accurate in testing the hypothesis. Again referring to the table below, all control variables are deemed significant based on the t-test, where they have p-values lower than 0.1. On the other hand, the interaction variable XBRL $\times$ GOV and independent variable XBRLenv are highly insignificant, which can be seen from their p-values of 0.515 and 0.468 . Also, based on the VIF results, it can be concluded that the model is free from multicollinearity problems. 
Table 2

Research Findings

\begin{tabular}{|c|c|c|c|}
\hline Variables & Coefficients & $\begin{array}{c}\text { t-stat } \\
\text { (p-value) }\end{array}$ & VIF \\
\hline Constant & -13756.848 & $\begin{array}{l}-1.877 \\
(.062)^{*}\end{array}$ & - \\
\hline XBRLenv & 5518.700 & $\begin{array}{l}0.728 \\
(.468)\end{array}$ & - \\
\hline Governance & -19109.812 & $\begin{array}{l}-2.311 \\
(.022)^{*}\end{array}$ & - \\
\hline $\mathrm{XBRL} \times \mathrm{GOV}$ & -7403.929 & $\begin{array}{l}-0.653 \\
(.515)\end{array}$ & - \\
\hline Size & 6191.866 & $\begin{array}{c}7.793 \\
(.000)^{*}\end{array}$ & 2 \\
\hline Capital Ratio & -12619.784 & $\begin{array}{l}-1.771 \\
(.078)^{*}\end{array}$ & 3 \\
\hline Leverage Ratio & 345.001 & $\begin{array}{c}2.575 \\
(.011)^{*}\end{array}$ & 2 \\
\hline ROA & -75296.605 & $\begin{array}{l}-2.647 \\
(.009)^{*}\end{array}$ & 1 \\
\hline Adjusted $R^{2}$ & $68.4 \%$ & & \\
\hline F-statistic & 56.446 & & \\
\hline Prob (F-statistic) & $(.000)$ & & \\
\hline
\end{tabular}

\footnotetext{
*Significant at $\alpha=10 \%$

SRisk $=$ The amount of capital financial institution $i$ needs at time $t$ amidst events of financial crisis; XBRLenv $=$ a dummy variable where 0 represents company $i$ operating prior mandatory XBRL adoption and 1 represents company $i$ operating post mandatory XBRL adoption; Governance $=$ index based on Gov-Score by Brown \& Caylor, (2006); XBRL $\times \mathrm{GOV}=$ an interaction variable between XBRLenv and Governance; Size $=$ the natural logarithm of the total assets of company $i$ at time $t$; Capital Ratio $=$ the ratio of the amount of assets company $i$ holds that are financed by equity at time $t$ (total equity divided by total assets); Leverage Ratio = the ratio of the amount of equity company $i$ holds that are financed by debt at time $t$ (total liability divided by total equity); ROA = the performance of company $i$ at time $t$ (net income divided by total assets).
}

As mentioned in section 2, it is expected that the systemic risk of financial institutions will be lower post the adoption of XBRL, where it is believed that XBRL can improve corporate governance which will in turn reduce systemic risk. Based on the regression results shown in the above table, the relationship between SRisk and XBRL $\times \mathrm{GOV}$ is in accordance to what has been hypothesized. Nevertheless, by referring to the $t$ test results for XBRL $\times \mathrm{GOV}$, it indicates that it is not significant in explaining the variances of SRisk. Thus, it can be concluded that there is insufficient evidence to reject null hypothesis, where corporate governance in the context of XBRL do not significantly affect systemic risk of financial institutions listed in NYSE. Such result may have been driven by the fact that the individual XBRLenv variable has no significant relationship with SRisk. This signifies that the firms' exposures towards systemic risk are generally not affected by the implementation of XBRL. Based on the theories discussed in section 2, it is expected that XBRL can reduce systemic risk by acting as the potential common delivery system to strengthen corporate governance through the enhancement of market 
discipline. The insignificant regression results have further raised a question on how XBRL fails to influence systemic risk. One of the most possible explanations has been outlined in the studies of Angkinand et al. (2011), Kunt et al. (2008), Nier \& Baumann (2006) and McCoy (2006). According to Angkinand et al. (2011), debt holders of financial institutions lack the incentive to perform monitoring functions in complement of regulations. They are reluctant to gather the necessary information and act on it. Debt holders, which represent the largest portion of the stakeholders of financial institutions (especially banks), have their stakes protected by deposit insurance. The extrinsic and intrinsic deposit insurance provides the creditors with high financial safety net. In particular, the intrinsic deposit insurance arises from experience, where previous government bailouts of collapsed financial institutions serve as evidences that similar bailouts will take place if the event is to occur in the future (Kunt et al. 2008). Meanwhile, the extrinsic deposit insurance formally commits in advance on the return of partial or full amount of the deposits of failed financial institutions. As a result, creditors believe that they are immune towards the risk of potential loss in the case of default, which leads to the problem of moral hazard. Moral hazard refers to the lack of incentives in safeguarding oneself against the risk of possible losses, as one has been protected from the outcome of such risk. The problem of moral hazard has caused the lack of motivation for stakeholders to act as external monitors. McCoy (2006) even stated that insured depositors will not demand a risk premium or exert pressure when banks are making unnecessary risky loans, as they expect government blanket guarantee for their deposits in times of financial distresses. Such function is actually essential in maintaining a strong market discipline. A strong market discipline arises when high quality of information is available for stakeholders to assess the risk associated with the activities undertaken by the firms. However, the problem of moral hazard clearly blunts the market discipline of financial institutions. Hence, the increase in understandability and transparency of information provided by XBRL to improve market discipline becomes abundant. As market discipline is not affected by XBRL, the risk taking activities of financial institutions fail to be mitigated. As a result, systemic risk of financial institutions is generally unaffected by the presence of XBRL.

Additionally, the coefficient for XBRL $\times$ GOV (-7404) indicates a negative relationship between the two variables. To provide further analysis over such relationship, it is important to observe the effect of individual Governance variable towards SRisk. The Governance variable alone has a significant negative impact towards SRisk. It indicates that a strong corporate governance mechanism of financial institutions will in fact, be able to reduce systemic risk. This finding is in contrast to what have been found by Iqbal et al. (2015). Iqbal et al. (2015) argued that corporate governance mechanisms of financial institutions contain flaws and are still in need of a tool to limit their risky behaviors. Such contrasting findings may be explained by the difference in the time horizon of the sample taken. Iqbal et al. (2015) documented his finding based on a sample within the years of 2005 and 2010, while this research has taken into account the years of 2011 and 2012. Hence, this research provides an updated finding over the impact of corporate governance towards systemic risk. Post crisis, many reforms have been made over the regulations governing the activities of financial institutions. In particular, the 2010 Dodd Frank Act and the Third Basel Accords have been implemented to provide tighter supervisions over financial institutions in order to prevent the crisis from occurring again. Many regulations which include updated capital adequacy requirements, stress testing and market liquidity risk have been aimed to reduce financial institutions' exposures towards systemic risk. Therefore, the implementation of such regulations may have covered the flaws in the corporate governance of 
financial institutions which enabled them to effectively limit the risky behaviors of financial institutions. The findings made by Iqbal et al. (2015) have not taken into account such reforms as most of them came into effect only after 2010 .

The regression results for all the control variables are as predicted. The coefficient sign for each control variable is as expected and based on the $t$ test, such results are deemed to be significant. To begin with, the first control variable, Size has a coefficient of +6192 . The positive sign indicates a positive relationship with the dependent variable. Such finding is consistent with those of Iqbal et al. (2015) and Brunnermeier et al. (2012) where larger financial institutions are expected to contribute more towards the overall systemic risk. This is due to the fact that that the growth in the size of financial institutions reflects the increase in opacity and complexity of their activities, which makes it more difficult to detect their excessively risky behaviors. Furthermore, large sized firms have many more stakeholders than smaller sized firms, which as a result, increase the significance in their activities. The second control variable, Capital Ratio has a regression result that is consistent with the findings of Iqbal et al. (2015) and Brunnermeier et al. (2012). The coefficient of - 12620 indicates that it is negatively associated with systemic risk. Financial institutions with higher capital ratio have high amount of capital that can act as buffers during events of financial crisis. The retention of high capital ratio also limits the firms' ability to undergo excessive risk taking activities, which in turn reduces their exposures towards systemic risk. The third control variable, Leverage Ratio has a positive coefficient of +345 . This serves as evidence for the theory suggested in the study of Laeven (2012). The study believes that Leverage Ratio must be directly associated with systemic risk. Firms with high leverage ratios correspond with highly risky behaviors where it indicates that the specific firms rely on high debt levels. As most of their capitals have been financed by debts, these firms are believed to have high systemic risks as they are expected to experience high default risks during financial turmoil. The fourth and last control variable, ROA is a measure for firm performance. It has a coefficient of - 75297, which indicates that, the increase in the performance of financial institutions result in the decrease in systemic risk. Such finding is consistent with that of Iqbal et al. (2015) who found the same association between the two variables.

\section{Conclusion and Recommendation}

The role of financial institutions is very critical in the economy. However, the very nature of their interconnectedness, complexity and opacity has rendered them to high degree of systemic risks. The negative externalities of having exposed to such risks can be seen from the recent 2008 global financial crisis. Financial institutions prior crisis engaged in excessively risky behaviors. Such behaviors amplified their exposures to systemic risk and in particular, were undetected by their corporate governance mechanisms. Many studies have claimed the lack in market discipline has caused the governance failure. A possible solution to solve such failure is the implementation of a common delivery system which serves as a tool to improve market discipline. This will strengthen the ability of corporate governance to detect the risky behaviors of financial institutions, which eventually reduces their exposures towards systemic risk. Existing literatures have documented that XBRL has the potential to serve as the common delivery system as it can improve market discipline by enhancing information transparency and understandability. When users of financial information are able to understand and receive good quality of information in the form of XBRL instance document, they can exert pressures on 
financial institutions that are undergoing excessive risk taking activities. As a result, financial institutions are forced to maintain high amount of capital and have limited ability to take on debt which help reduces their exposures towards systemic risk. Nonetheless, there have been no studies that have studied the impact of XBRL implementation specifically to the financial industry and also its impact towards systemic risk. Therefore, this research aims to examine the impact of XBRL implementation towards systemic risk in the context of NYSE listed financial institutions. The impact of firm size, capital ratio, leverage ratio and performance on systemic risk will also be studied.

This research is motivated by that of Iqbal et al. (2015) who found a somewhat counterintuitive result in which corporate governance positively impact systemic risk based on the value maximization principle. This research however, adds a new perspective in which the corporate governance variable is interacted with XBRL. It is expected that XBRL serves as the suitable tool to improve corporate governance which therefore, results in a negative association with systemic risk, in contrast to that of Iqbal et al (2015). Nevertheless, this research found that the impact of corporate governance towards systemic risk becomes insignificant when XBRL is added. It shows that XBRL do not have any impact towards systemic risk. The reason for having obtained such result may have been explained by existing studies of market discipline. The effectiveness of market discipline in financial industry has been blunted by the existence of moral hazard. The problem of moral hazard arises from explicit and implicit deposit insurance, in which stakeholders (particularly creditors) become neglected towards the activities of financial institutions. As a result, the ability of XBRL to improve quality of information available to the stakeholders is generally ignored. Furthermore, the associations between the control variables and systemic risk are all significant and as hypothesized. Size and leverage ratio positively impact systemic risk while capital ratio and firm performance (ROA) have negative influence on systemic risk.

In practice, this study is expected to have several implications. First, particularly for the American government and standard setters, the finding suggests that XBRL failed to act as a tool to limit the risky behaviors of financial institutions. Therefore, they cannot rely on the implementation of XBRL to solve problems related to the excessive risk taking activities of financial institutions. It has also been found that the size and leverage ratios of financial institutions positively affect systemic risk. On the other hand, capital ratio and ROA (Return on Assets) negatively impact systemic risk. Based on these findings, it can be implicated that American standards setters and regulatory bodies must closely monitor poorly performing financial institutions that are large in size, have low capital ratios and are highly leveraged. Second, as this study can be considered as the first of its kind, it can serve as a starting point for further research over the implementation of XBRL in the financial industry. It may attract academicians and students, who are willing to further explore the possible benefits that XBRL can provide. This may include its ability to reduce earnings management and detect off-balance sheet transactions, etc. Moreover, through the findings of this study, it can be seen that XBRL has failed to reduce systemic risk. Nonetheless, this research also found that stronger corporate governance reduces financial institution's exposure towards systemic risk. This finding is in contrast to that of prior researches. Prior researches documented that corporate governance mechanisms of financial institutions are still in need of a tool to reduce systemic risk. This has been empirically proven by the fact that good corporate governances actually increased systemic risk. Hence, the negative association between corporate governance and systemic risk found in this research proves that corporate governance of financial institutions is no longer suffering 
from inefficiencies to limit risky behaviors. This amplifies the interest in recognizing the tool that has actually caused such relationship. Through this study, it has been proven that XBRL failed to act as the appropriate tool. Post crisis, many reforms have been made on the regulations of financial institutions, such as the Dodd Frank Act and the Third Basel Accords. Therefore, it will certainly be interesting to conduct a study regarding the effect of such reforms towards the systemic risk and corporate governance of financial institutions.

\section{References}

Acharya, V.V. \& Richardson, M. (2009). Causes of financial crisis. Critical Review: A Journal of Politics and Society (195-210). DOI: 10.1080/08913810902952903

Acharya, V., Engle, R., \& Richardson, M. (2012). Capital shortfall: A new approach to ranking and regulating systemic risks. American Economic Review Papers and Proceedings, 102(3), 59-64. DOI: 10.1257/aer.102.3.59

Angkinand, A.P., Wihlborg, C. \& Willett, T.D. (2011). Market discipline for financial institutions and markets for information. Research Handbook on International Banking and Governance, Forthcoming . Retrieved from http://ssrn.com/abstract=1886485 https://doi.org/10.2139/ssrn.1886485

Arnold, V., Bedard, J.C., Phillips, J.R., \& Sutton, S.G. (2012). The impact of tagging qualitative financial information on investor decision making: implications for XBRL. International Journal of Accounting Information System, 13 (2-20). DOI: 10.1016/j.accinf.2011.12.002

Blankerspoor, E., Miller, B. P., \& White, H. D. (2012). Initial evidence on the market impact of the XBRL mandate. Review of Accounting Studies, 19 (1468-1503). Retrieved from https://www.researchgate.net https://doi.org/10.1007/s11142-013-9273-4

Bullard, J., Neely, C.J. \& Wheelock, D.C. (2009). Systemic risk and the financial crisis: A Primer. Federal Reserve Bank of St. Louis Review, 91 (Part 1). Retrieved from https://research.stlouisfed.org

Bushman, R.M. (2015). Transparency, accounting discretion and bank stability. Economic Policy Review, Forthcoming. Retrieved from https://www.newyorkfed.org

Brown, L.D. \& Caylor, M.L. (2006). Corporate governance and firm valuation. Journal of Accounting and Public Policy, 25 (409-434). DOI: 10.1016/j.jaccpubpol.2006.05.005

Brunnermeier, M.K., Dong, G., Palia, D., 2012. Banks' non-interest income and systemic risk. Working Paper. Retrieved from https://www.princeton.edu

Claessens, S. (2006). Corporate governance and development. Oxford University Press, 21 (91122). DOI:10.1093/wbro/lkj004

Dhouibi, R., Mabrouk, A., \& Rouetbi, E. (2016). Bank transparency and risk taking: Evidence from Tunisia. International Journal of Economics and Finance, 8 (5). DOI:10.5539/ijef.v8n5p111

Diamond, D.W., \& Verrecchia, R.E. (1991). Disclosure, liquidity, and the cost of capital. Journal of Finance, 46 (1325-1359). Retrieved from http://links.jstor.org https://doi.org/10.1111/i.1540-6261.1991.tb04620.x

Erkens, D.H., Hung, M. \& Matos, P. (2012). Corporate governance in the 2007-2008 financial crisis: Evidence from financial institutions worldwide. Journal of Corporate Finance. DOI:10.1016/j.jcorpfin.2012.01.005

IASB. (2013). A review of the conceptual framework for financial reporting. IASB Discussion Paper. Retrieved from http://www.ifrs.org 
Ilias, A., Razak, M.Z.A., \& Rahman, R.A. (2015). The expectation of perceived benefit of extensible business reporting language (XBRL): A case in Malaysia. The Journal of Developing Areas, 49 (263-271). DOI: 10.1353/jda.2015.0060

Iqbal, J., Strobl, S., \& Vahamaa, S. (2015). Corporate governance and the systemic risk of financial institutions. Journal of Economics and Business. DOI: 10.1016/j.jeconbus.2015.06.001

Jickling, M. \& Murphy, E.V. (2010). Who regulates whom? An overview of U.S. financial supervision. Congressional Research Service. Retrieved from http://www.crs.gov

Kernan, K. (2008). XBRL around the world. Journal of Accountancy. Retrieved from http://www.journalofaccountancy.com

Kunt, A.D., Kane, E. \& Laeven, L. (2008). Deposit insurance design and implementation: Policy lessons from research and practice. The MIT Press Cambridge. Retrieved from https://mitpress.mit.edu

Laeven, L. (2012). Corporate governance: What's special about banks? Keynote lecture at the DNB-CGIC conference on corporate governance of financial institutions, Amsterdam, November 2012. Retrieved from http://www.dnb.nl

Leuz, C. \& Verrecchia, R. E. (2000). The economic consequences of information disclosure. Journal of Accounting Research, 38 (91-124). Retrieved from http://papers.ssrn.com/sol3 https://doi.org/10.2307/2672910

Levine, R.. (2004). The corporate governance of the banks: A concise discussion of concepts and evidence. Working Paper, World Bank Policy Research. Retrieved from https://core.ac.uk/download/pdf/6521435.pdf

Levine, R. (2012). The governance of financial regulation: Reform lessons from the recent crisis. International Review of Finance. DOI: 10.1111/j.1468-2443.2011.01133.x

Li, O.Z., Lin, Y., \& Ni, C. (2012). Does XBRL adoption reduce the cost of equity capital? Retrieved from https://papers.ssrn.com/sol3/papers.cfm?abstract_id $=2131001$

Liu, C., Luo, X., Sia, C. L., O'Farrell, G., \& Teo, H. H. (2013). The impact of XBRL adoption in PR China. Decision Support Systems, 59 (242-249). Retrieved from www.elsevier.com/locate/dss https://doi.org/10.1016/j.dss.2013.12.003

McCoy, P.A. (2007). The moral hazard implications of deposit insurance: Theory and evidence. Seminar on current developments of monetary and financial law Washington, D.C. Retrieved from https://www.imf.org

Mehran, H. \& Mollineaux, L. (2012). Corporate governance of financial institutions. Federal Reserve Bank of New York Staff Reports, 539. Retrieved from www.newyorkfed.org

Mehran, H., Morrison, A. \& Shapiro, J. (2011). Corporate governance and banks: What have we learned from the financial crisis? Federal Reserve Bank of New York Staff Reports, 502. Retrieved from www.newyorkfed.org

Morgan, D.P. (2002). Rating banks: Risk and uncertainty in an opaque Industry. American Economic Review, 92(4): 874-888. Retrieved from https://www.researchgate.net https://doi.org/10.1257/00028280260344506

Nier, E.W. \& Baumann, U. (2006). Market discipline, Disclosure and moral hazard in banking. Journal of Financial Intermediation 15 (332-361). DOI: 10.1016/j.jfi.2006.03.001

Premuroso, R.F. \& Bhattacharya, S. (2008). Do early and voluntary filers of financial information in XBRL format signal superior corporate governance and operating performance? International Journal of Accounting Information Systems, 9 (1-20). DOI:10.1016/j.accinf.2008.01.002 
Suwardi \&Tohang | An Analysis of XBRL Adoption Financial Institutions Listed in NYSE

Schnyder, G. (2012), Measuring corporate governance lessons from the bundled approach. Journals of Accounting Research, 438. Retrieved from http://www.cbr.cam.ac.uk

Weiß, N.F., Bostandzic, D., \& Neumann, S. (2014). What factors drive systemic risk during international financial crises? Journal of Banking \& Finance, 41 (78-96). DOI: 10.1016/j.jbankfin.2014.01.001

Yahoo Finance: NYSE Quote. (2016). Retrieved from https://finance.yahoo.com/quote

Yoon, H., Zo, H., \& Ciganek, A. P. (2010). Does XBRL adoption reduce information asymmetry? Journal of Business Research, 64 (157-163).

DOI:10.1016/j.jbusres.2010.01.008 